\title{
Terry Erwin's legacy: from taxonomy and natural history to biodiversity research and conservation biology
}

\author{
Thorsten Assmann' \\ I Institute of Ecology, Leuphana University Lüneburg, Universitätsstraße 1, 21335, Lüneburg, Germany \\ Corresponding author: Thorsten Assmann (assmann@uni.leuphana.de)
}

Academic editor: John Spence | Received 13 May 2021 | Accepted 14 May 2021 | Published 16 June 2021

http://zoobank.org/0507FA8E-A006-4B62-9791-DEBA4C4D9A14

Citation: Assmann T (2021) Terry Erwin's legacy: from taxonomy and natural history to biodiversity research and conservation biology. In: Spence J, Casale A, Assmann T, Liebherr JK, Penev L (Eds) Systematic Zoology and Biodiversity Science: A tribute to Terry Erwin (1940-2020). ZooKeys 1044: 23-39. https://doi.org/10.3897/zookeys.1044.68650

I first met Terry Erwin, already an icon of biodiversity research, at the fantastic $20^{\text {th }}$ International Congress of Entomology in Florence in 1996. His high level of scientific expertise, open mind, cooperative attitude, and enthusiasm for carabids overawed me immediately. Terry also radiated interest in other insects and whole ecosystems. Over the years, these traits have inspired many others, especially young scientists and students, as is clearly evident in the contributions of this issue (e.g. Spence 2021; Grammer 2021) and Kavanaugh (2020). In addition to Terry's human qualities, his basic natural history approach to scientific research has significantly shaped his life's work.

From my time as a graduate student, I literally devoured Terry's publications, as his research made a deep impression on me. This was largely because Terry's work was broad, ranging from classical taxonomy and natural history to sophisticated analyses of biodiversity and ecosystem services. I believe that Terry's body of research is up-to-date and in many ways timeless, and that it will leave a lasting mark because of its broad organismic approach to biology. In this essay, I will briefly highlight what I regard as his most important research in a way that I hope will encourage others to read or even reread it. That might be the way Terry would have been most happy to be remembered.

Copyright Thorsten Assmann. This is an open access article distributed under the terms of the Creative Commons Attribution License (CC BY 4.0), which permits unrestricted use, distribution, and reproduction in any medium, provided the original author and source are credited. 


\section{Taxonomy}

Terry Erwin started his research about carabid beetles with a taxonomic revision of the North American brachinines, a charismatic group of ground beetles with a famous explosive defense mechanism. Terry's taxonomic revision with the description of new taxa appeared in 1970, but also included earlier works (Erwin 1965, 1969a, b, 1970a). His taxonomic contributions are characterized by especially comprehensive treatments of morphology, species descriptions, but also phylogenetic analyses following the principles laid out by Hennig (1969), which were a principal innovation in taxonomy at the time of Terry's earliest studies. This approach underscores the influence of George E. Ball, Carl H. Lindroth, and P.J. Darlington, themselves giants in carabid systematics, who were his mentors. For carabidologists outside North America, it is especially significant that the relationships and systematics of related genera and higher taxonomic entities of the subfamily were included in Terry's taxonomic revisions. This resulted in a work of lasting value that is still relevant today, after half a century, and used, not only as a basis for identifications, but for further systematic work.

Such treatments of taxonomically challenging ground beetle groups were a hallmark of Erwin's scientific career. He worked both alone and with co-authors in this thorough way mainly on carabid taxa from the Americas. Work on the taxa Leistus, Xystosomus, and several Agra species groups provide excellent examples of the approach (e.g., Erwin 1970b, 1973, 1978, 1982a, b, 1983, 1984, 2002). He also worked on ground beetles on a world scale (e.g., Hiletini et al. 1985). These excellent taxonomic contributions undoubtedly represent the core of his scientific activity. Altogether, he has described 30 (sub-) genera and 438 species (ZooKeys Editorial Office 2015; Penev et al. 2021). Through his alpha-taxonomic achievements as well as the clarification of phylogenetic relationships, he contributed significantly to the systematics of the Carabidae and laid firm foundations for many future research activities.

Excellent taxonomic publications clarify the morphological characters central to the identification of the given taxa. For this purpose, one often uses illustrations, usually drawings or photographs. Terry had his own style for such illustrations. His line drawings, which focus on the essential features and partly also emphasize them (see for an example Fig. 1), have been particularly helpful to me for identification of species. In his later works, photographs of the beetles' habitus and other details are added (see for example Figs 2,3 ). These effective photographs were mostly taken by professional photographers working in Smithsonian Museum's Entomology Department, but Terry's careful supervision ensured that they revealed the critical features required for accurate identifications.

His identification keys are generally suitable for taxonomic laypersons (e.g., Erwin and Kavanaugh 2000). This approach to taxonomy, not just for its own sake, but also as a service for other scientists, distinguishes great taxonomists like Terry from those with more limited influence, in my opinion. This personal carriage is amplified by Terry's commitment to updating the last great work that Carl Lindroth was unfortunately unable to complete before his death. Terry revised of Lindroth's key down to the generic 

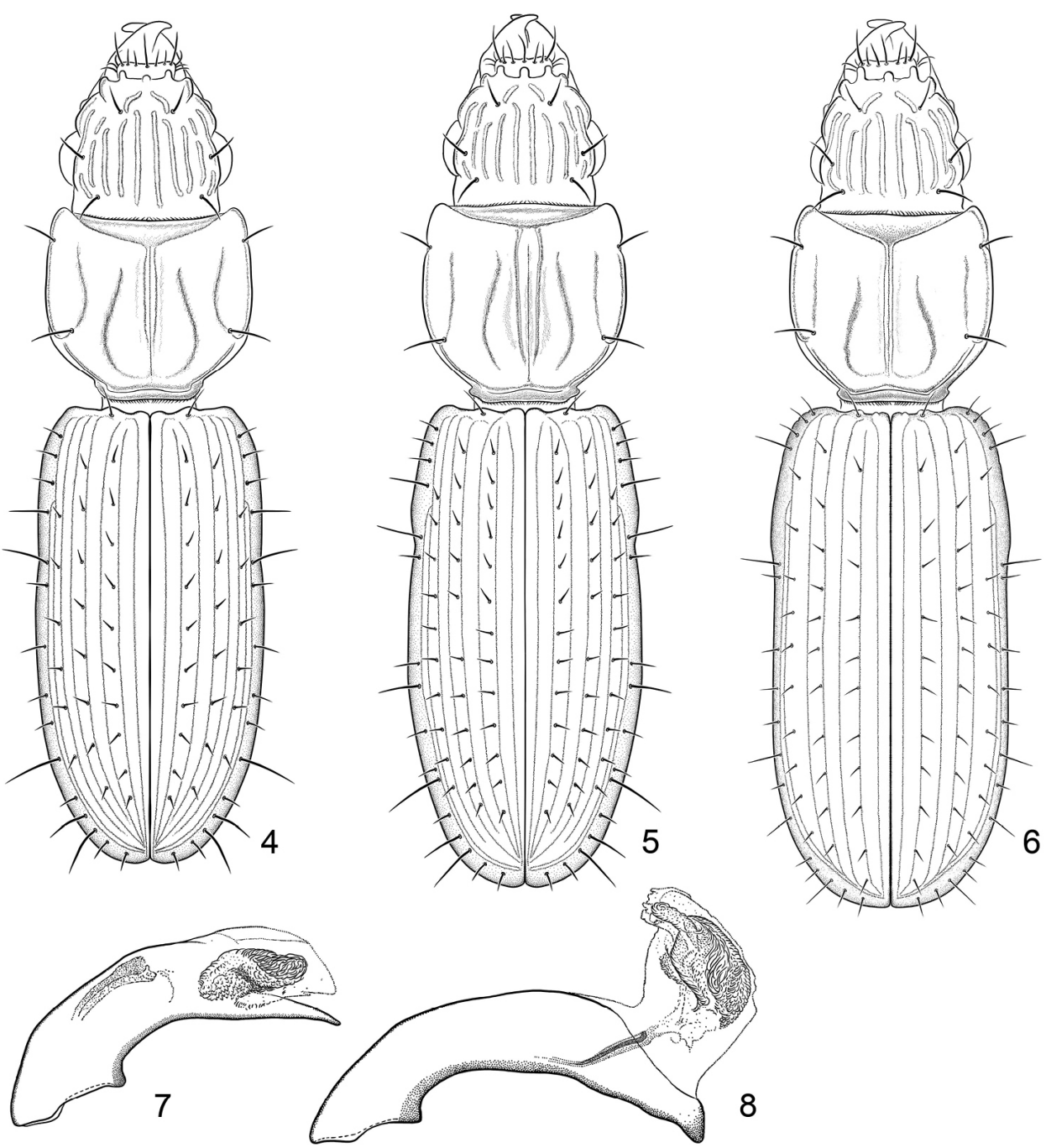

8

Figure I. Example of Terry Erwin's line drawings: dorsal aspects of three Halocoryza species and the median lobe of aedeagus of two Halocoryza species. From Erwin (2011: figs 4-8).

level and wrote a chapter on a modern systematics of the northern carabids (Lindroth et al. 1985, 1986). In this way, Terry contributed to this work which is widely used by carabidologists, not solely from Scandinavia, but also from other European countries.

Working with a huge collection of beetles means that a curator must also engage with other collections, curators, and collectors. A broad appreciation of systematic work is required that extends into the historical dimension. In this context, Terry produced some fine papers that honored outstanding systematists like Maximillien de Chaudoir as well as citizen scientists like Max Bänninger (Erwin and Halpern 1978; Ball and Erwin 1983; Erwin 1983). 

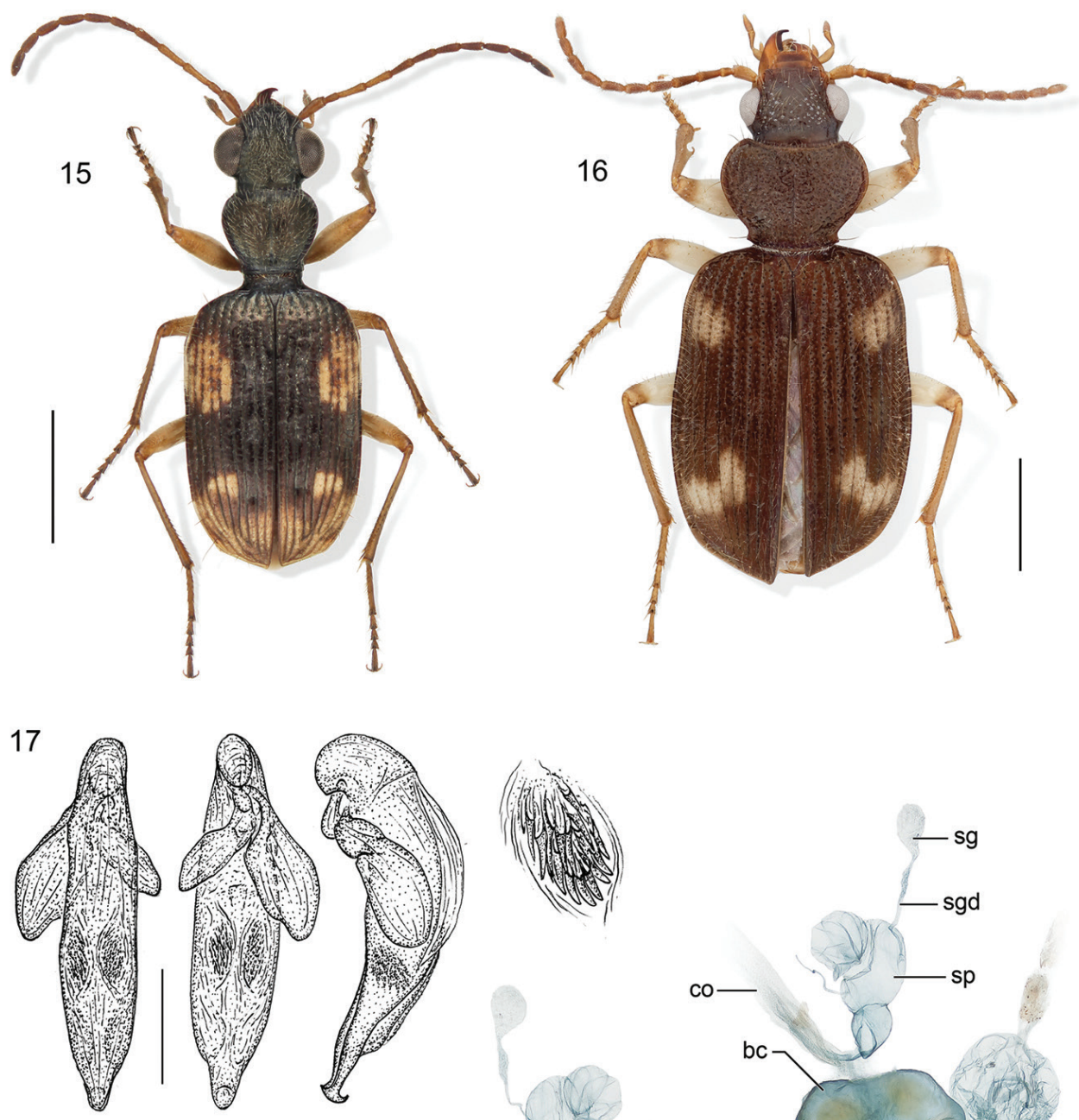

18

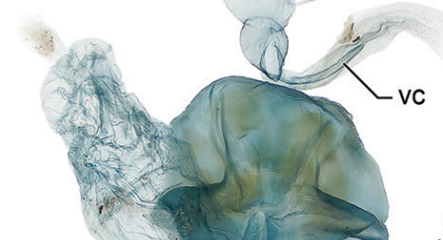

A

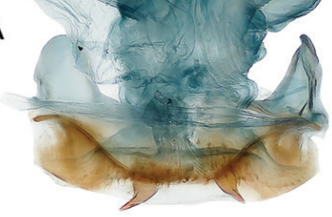

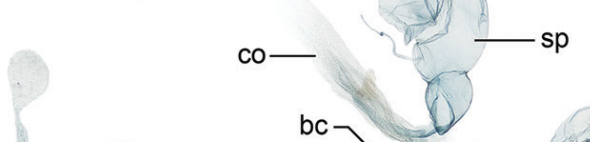

des

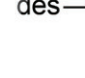

B

Figure 2. Example of Terry Erwin's diverse illustrations: habitus, male genitalia (median lobe of aedeagus, with parameres) in dorsal, ventral, and lateral view with enlarged details of the internal sac and female genitalia from Lachnophorus species. From Erwin and Zamorano (2014: figs 15-18). 

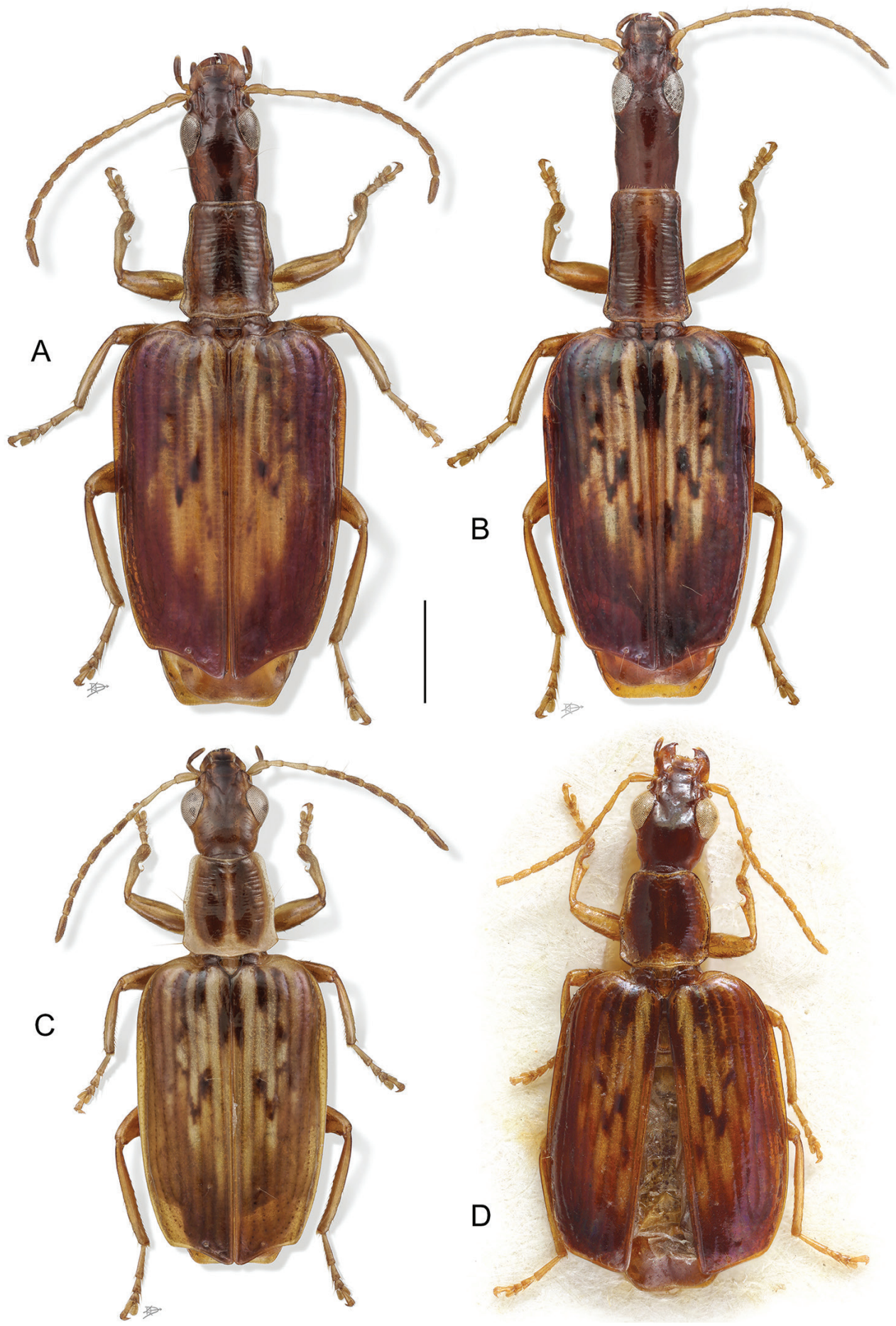

Figure 3. Example of Terry Erwin's habitus illustrations: habitus of four Straneotia species. From Erwin and Aldebron (2018: fig. 14). 
I was grateful to find a really extraordinary and useful work by Terry during a frustrating hour-long search for types in the dark, seemingly endless "canyons" between single collections of carabids in the Muséum national d'Histoire naturelle, Paris. He had created a presentation with maps to locate the specific carabidological collections stored in this huge museum and he made it available as a copy to the visitors. After I found this guide produced in 1971, it allowed me to efficiently succeed in meeting my goals 46 years later in 2017. This is a work of service that has lasting value! It has provided invaluable service to many carabidologists, I am sure of it! Any serious carabidologist who spends time in this fantastic museum will greatly appreciate this guide.

Joint awareness of an impediment to taxonomic publication and the central role of identification keys in organismic biology led Terry to initiate, with his friend, Lyubomir Penev, the taxonomic journal "ZooKeys" (Penev in Spence et al. 2021). Through Terry's leadership, Pensoft launched and established "ZooKeys" as a wellrespected international, peer-reviewed journal (Penev et al. 2008; Erwin et al. 2015) emphasizing rapid and effective taxonomic publication through modern web-based services and free access for readers (Erwin et al. 2012; Penev et al. 2012; Stoev et al. 2013). Clearly, "ZooKeys" has been a major accomplishment that supports modern work in zoological taxonomy as a basis for other biological disciplines.

\section{Natural history-based science}

As most taxonomists are also interested in other facets of their favorite organisms, Terry was most interested in the habits, food, behavior, and ecology of ground beetles. Thus, the natural history of ground beetles became an important focus of his research. Natural history can be understood as a field of endeavor that deals with species in their natural environment and that leans more towards observational and descriptive studies than toward experiments.

Terry worked on numerous fascinating phenomena ranging from ectoparasitic lifestyles (Erwin 1967; Frank et al. 2009) and myrmecophily (Erwin 2013; Erwin and Amundson 2013) to the diving behavior of Cicindis horni Bruch, 1908 associated with eating fairy shrimp (Erwin and Aschero 2004). His work on larval development of Brachinus species in North America is particularly well known (Erwin 1966, 1967, 1972) and this stimulated Europeans to find out more about the natural history of their bombardier beetle species (e.g., Saska and Honek 2004).

Many of Terry's observations have stimulated other entomologists and citizen scientists to observe and study behavior, development, and other aspects of the natural history of ground beetles. An example is his publication about the ectoparasitoidism of Eurycoleus macularis (Chevrolat, 1835) which develops on fungus beetles of the genus Amphix (Endomychidae), with larvae and adults both relying on the host as prey and living together with them (Erwin and Erwin 1976). More than 40 years later, Hunting and Yang (2019) reported that they found another percaline ground 
beetle in Taiwan, namely Lioptera erotyloides Bates, 1883, which is quite similar in coloration to fungus beetles of the subfamily Megalodacninae (Erotylidae). Ground beetles and fungus beetles were encountered together. However, the authors could not detect any trophic interaction between the beetles. Lioptera erotyloides is more widely distributed in subtropical East Asia and is also found in the Gutianshan National Park (China). Zumstein et al. (2021) were able to detect both this pericaline species and comparably colored erotyloids in flight interception traps there, but we were not able to observe the species alive in the field. However, the parallels shown here between ground beetles and fungus beetles are striking. Thus, Erwin and Erwin (1976) may have described a pattern of ectoparasitoid behavior for pericalines that is more widespread than previously known.

Erwin and Stork (1985) revised the Hiletini, a pantropically distributed group of ground beetles with large, hemispherical mandibles. Terry was fascinated by Hiletini species and spent many nights in the field watching them, hoping to discover more about their way of life. Although he published the only note about feeding habits of a member of this ground beetle tribe (Erwin 2011), I expect that he regretted being able to clearly understand how these beetles hunt and consume their prey using their distinctive mandibles.

Observational studies set bases for understanding trophic interactions, behavior, phenology, and many other phenomena. In a modern terminology natural history contributes to understanding ecological traits which are, in turn, essential for an understanding of the mechanisms which shape community structures and drive species to extinction (e.g., Gerisch et al. 2012; Homburg et al. 2014; Nolte et al. 2017). Terry's natural history approach aimed to compile ecological traits of species across whole regions. His later regional monographs attempted to include all carabid species, and he aimed to develop comprehensive databases of ecological and distributional traits for this region. This approach resulted, for example, in the series 'A treatise on the Western Hemisphere Caraboidea (Coleoptera): Their classification, distribution, and ways of life' (Erwin 2007, 2011; Erwin and Pearson 2008).

The importance of this kind of natural history is often underestimated, and its decline in academia is rather staggering (e.g., Tewksbury et al. 2014). However, there are now young scholars who emphasize the importance of natural history for a modern development of organismic biology (Christenhusz 2020). Thus, Terry's work in natural history (and related ecological fields) doubtlessly contribute to essential basic work in organismic biology and we may hope help inspire a more emphasis on natural history as a basis for integration of systematics and ecology.

\section{Biodiversity studies and fogging}

Terry's publication about beetles collected by fogging on the tree species Luehea seemannii fired up a debate about arthropod species richness on Earth and was central to founding the discipline of biodiversity science (Erwin 1982). Although today most 
think that there are fewer species than Erwin first predicted based on his initial fogging study (e.g., Hamilton et al. 2013; Stork 2018), questions inspired by this work are still intensively discussed almost four decades later. These include, for example, relationships of species diversity among taxonomic groups (Garcia-Robledo et al. 2020), and the proper methods to upscale species numbers from small study sites to large areas (Basset et al. 2012; Schuldt et al. 2015; Staab and Schuldt 2020). GarciaRobledo et al. (2020) further developed Terry's arguments about the ratio between insect and plant species diversity into a diversity-ratio model, which is called by the authors the 'Erwin Equation of Biodiversity'. In addition, these authors illustrate how Terry's work inspired other scientists to refine biodiversity estimates to determine insect numbers more accurately.

In my opinion, the 1982 paper in "The Coleopterists Bulletin" is special not only in inspiring the diversity-ratio approach, but in the fact that Terry really tried measure species diversity in a defined area of tropical forest. He was among the first to bring this into the realm of science by framing general the effort to understand biodiversity in terms of hypothesis testing. Terry made it clear in the lively debate about his estimate of species number that the point was not whether he had been right or wrong, but that measurements should be used in science to test hypotheses. In this case the ultimate goal was providing the best estimate possible of the number of species on Earth based on measurements from the living world, rather than counts from taxonomic catalogues. He underscored this position in his contribution to the famous book edited by Edward O. Wilson, which ultimately initiated the introduction and thus acceptance of the term 'biodiversity' among scientists and the general public worldwide (Erwin 1988). Biodiversity emerged as a living concept instead of one scientifically reflected mainly in the non-living content of museums. The emphasis changed from counting up what was named and known, to trying to understand the dimensions of what was unknown about life on Earth.

Terry developed the fogging as a sampling method for his research about tropical canopy faunas. The general method had perhaps been first employed by Roberts (1973). However, Terry modified and standardized the fogging with insecticides and catapulted an appreciation of the technique into the general awareness of biologists worldwide (e.g., Erwin 1983). It is now mentioned in textbooks as an important sampling method (e.g., Samways et al. 2010; Gullan and Cranston 2014). Terry's success in revealing the surprising arthropod abundance in canopies, including many new species, initiated many further studies of species diversity in this forest stratum that had long gone unnoticed (Stork 1991; Longino et al. 2002; Novotny and Basset 2005; Basset et al. 2012).

Terry not only used classical cladistic approaches in his research, but also explored the mechanisms leading to the enormous diversity of species, especially the life forms and radiations of carabids. He developed the 'taxon pulse model' to explain this extraordinary diversity (Erwin 1979, 1981, 1985). This hypothesis considered many aspects of ground beetle biology and proposed a unidirectional origin of arboreal carabids with their numerous morphological features from ground-dwelling ancestors. 
Overall, the hypothesis was innovative, comprehensible, and logical, and it was cited and discussed by numerous carabidologists, although modern molecular approaches have shown that carabids do not follow the postulated evolutionary paths as suspected (Ober 2003). Terry nonetheless appreciated that the idea had been tested scientifically.

\section{Conservation biology and ecology, especially of tropical rainforests}

Terry was genuinely excited about ground beetles in tropical rainforests and spent as much time as possible over the past decades in the field. Thus, he experienced firsthand the destruction of rainforest and the threat to vast areas that remain. Conservation-related research therefore seemed important to him, but he did not forget his taxonomic roots. In fact, he wrote or co-authored several publications positioned at the interface between conservation biology and taxonomy (Erwin 1991; Kemmer et al. 1993; Kress et al. 1998; Erwin et al. 2005).

Terry's extensive field experience, built up over decades, made him a highly desired cooperating partner in numerous projects. These projects addressed numerous questions of modern ecology and climate change that related directly to the biology of tropical rainforests. Examples include work about drought sensitivity (Phillips et al. 2009), forest biomass (Baker et al. 2004a, b), carbon cycle and storage (Fauset et al. 2015; Sullivan et al. 2017).

One of Terry's contributions about conservation biology was published in Science (Erwin 1991) and prompted lively discussion (e.g., Moritz et al. 2000; Avise 2001; Brooks et al. 2006; Frankham et al. 2009). The paper has collected more than 200 citations through April 2021 according to the ISI Web of Science. In that paper, Terry explained the idea that areas with numerous young (and phylogenetically related) species are important for maintaining evolutionary processes that generate extraordinary species diversity. The tropical rainforest comprises many such areas and Terry reasoned that their evolutionary function must depend on a system of highly interconnected habitats to conserve the evolutionary and adaptive potential of radiating lineages on the long term (Erwin 1991). This, of course, makes a conceptual case for conservation of large tracts of rainforest habitat.

\section{Connectivity of Terry's research activities}

The many facets of Terry Erwin's research activities are impressive in both depth and intellectual scope. However, most significant and likely most enduring aspects of Terry's research relate to human understanding of the Carabidae and are best appreciated when the results are aggregated at the level of taxa.

The significance of this impact struck me in a wadi close to the Dead Sea, when students on a field trip found a large bombardier beetle of the genus Pheropsophus (Fig. 4). The defensive mechanism, incorporating explosive chemistry, heat-resistant 


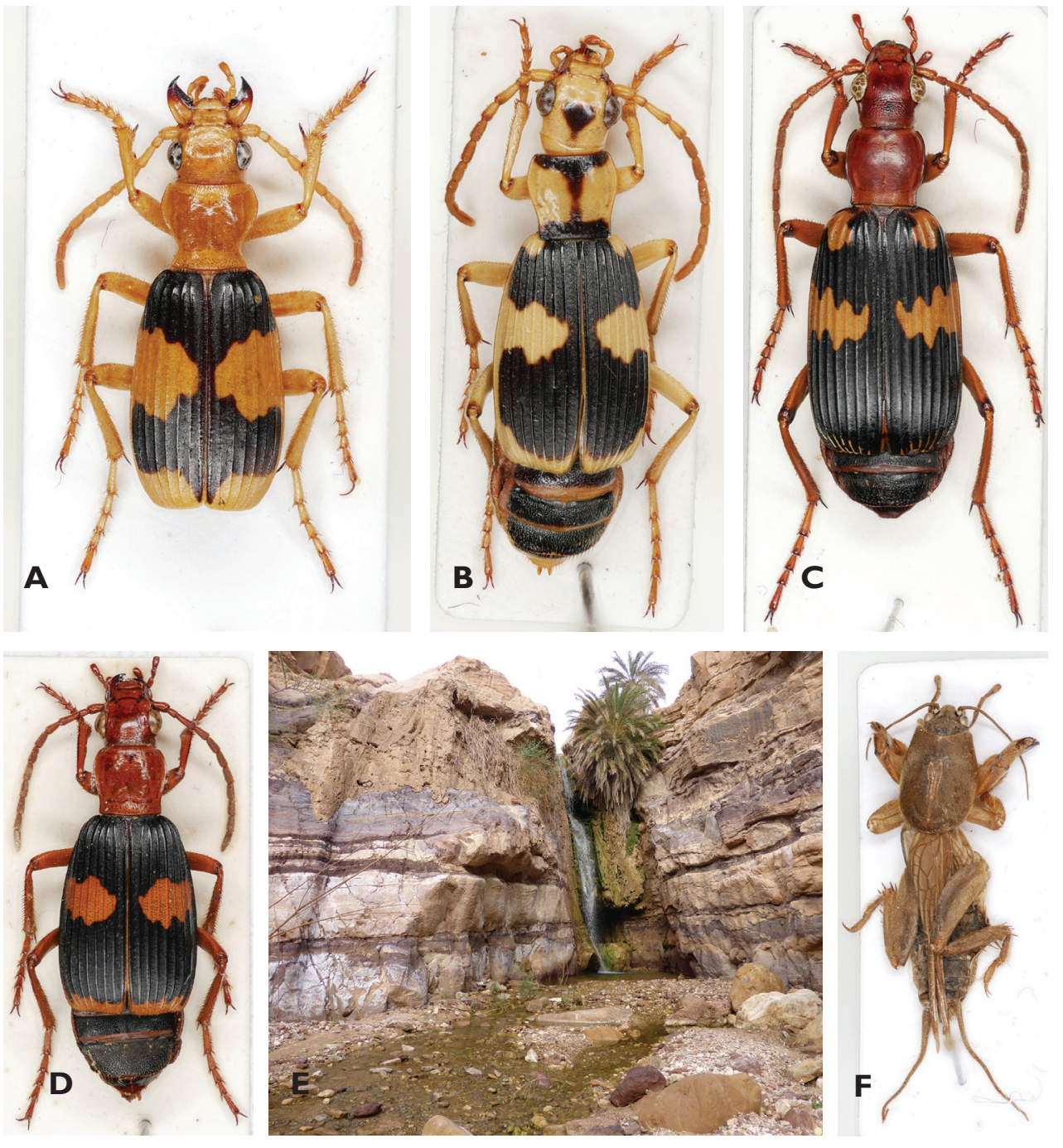

Figure 4. Bombardier beetles of the genus Pheropsophus, habitat of Pheropsophus africanus, and a Gryllotalpa specimen from the given habitat A $P$. (s. str.) aequinoctionalis (Linnaeus, 1763) B $P$. (Stenaptinus) jessoensis A. Morawitz, 1862 C P. (Stenaptinus) hispanus (Dejean, 1824) D P. (Stenaptinus) africanus (Dejean, 1825) E habitat of $P$. africanus (Jordan, northeast of Dead Sea) F Gryllotalpa spec.

enzymes, sound, and small quinone-containing puffs, was certainly impressive. Afterwards, the students learned that Terry Erwin had studied this group of ground beetles in North America and analyzed the hypermetamorphosis associated with the beetles' most interesting ectoparasitic lifestyle. Given his taxon-based focus, Terry had worked on representatives of the genus Pheropsophus from both America and the eastern Palaearctic (Fig. 4A, B). According to his co-authored publication (Frank et al. 2009), the larvae of these species develop in egg chambers of mole crickets. Therefore, the 
students on my field trip started searching for mole crickets and their typical burrows close to the stream. We found Gryllotalpa species not only at all sites with $P$. africanus in North Africa and the Middle East (Fig. 4D, E, F), but also at those with P. hispanus in Andalusia and Morocco. Although we have not confirmed the intimate relationships between these brachinids and mole crickets, Terry's work gave these students a place to begin unravelling trophic interactions between the western Palearctic Pheropsophus species (Fig. 4C, D) and gryllotalpids. The work of great biologists contributes in this way to a growing understanding of the Earth's biota. In his life, Terry Erwin was an active and significant contributor to such scientific understanding and his work will continue to inspire students of natural history and the systematics of the Carabidae long after his passing.

For making so many fertile linkages for carabidology and broader scientific disciplines we must be deeply grateful to Terry. I am sure that he will be long remembered not only as a great person and gifted natural historian, but also as an outstanding, versatile, and productive scientist.

\section{References}

Avise J (2001) Phylogeography: The history and formation of species. Harvard University Press, Cambridge, Massachusetts, 447 pp.

Baker TR, Phillips OL, Malhi Y, Almeida S, Arroyo L, Di Fiore A, Erwin T, Higuchi N, Killeen TJ, Laurance SG, Laurance WF, Lewis SL, Monteagudo A, Neill DA, Vargas PN, Pitman NCA, Silva JNM, Martinez RV (2004a) Increasing biomass in Amazonian forest plots. Philosophical Transactions of the Royal Society B-Biological Sciences 359: 353-365. https://doi.org/10.1098/rstb.2003.1422

Baker TR, Phillips OL, Malhi Y, Almeida S, Arroyo L, Di Fiore A, Erwin T, Killeen TJ, Laurance SG, Laurance WF, Lewis SL, Lloyd J, Monteagudo A, Neill DA, Patino S, Pitman NCA, Silva JNM, Martinez RV (2004b) Variation in wood density determines spatial patterns in Amazonian forest biomass. Global Change Biology 10: 545-562. https://doi. org/10.1111/j.1365-2486.2004.00751.x

Ball GE, Erwin TL (1983) The Baron Maximilien de Chaudoir: Inheritance, associates, travels, work, and legacy. The Coleopterists Bulletin 36(3): 475-501.

Basset Y, Cizek L, Cuenoud P, Didham RK, Guilhaumon F, Missa O, Novotny V, Odegaard F, Roslin T, Schmidl J, Tishechkin AK, Winchester NN, Roubik DW, Aberlenc HP, Bail J, Barrios H, Bridle JR, Castano-Meneses G, Corbara B, Curletti G, da Rocha WD, de Bakker D, Delabie JHC, Dejean A, Fagan LL, Floren A, Kitching RL, Medianero E, Miller SE, de Oliveira EG, Orivel J, Pollet M, Rapp M, Ribeiro SP, Roisin Y, Schmidt JB, Sorensen L, Leponce M (2012) Arthropod diversity in a tropical forest. Science 338: 1481-1484. https://doi.org/10.1126/science.1226727

Brooks TM, Mittermeier RA, da Fonseca GAB, Gerlach J, Hoffmann M, Lamoreux JF, Mittermeier CG, Pilgrim JD, Rodrigues ASL (2006) Global biodiversity conservation priorities. Science 313: 58-61. https://doi.org/10.1126/science.1127609 
Christenhusz MJM (2020) On species concepts, phylogenetics and the science of natural history - three current issues facing taxonomy. Megataxa 1: 67-72. https://doi.org/10.11646/ megataxa.1.1.14

Erwin TL (1965) A revision of Brachinus of North America: Part I. The California species (Coleoptera: Carabidae). The Coleopterists Bulletin 19(1): 1-19.

Erwin TL (1966) Brachinus pallidus Erwin, a carabid beetle with an entomophagous larva. Pan-Pacific Entomologist 42(1): 1-73.

Erwin TL (1967) Bombardier beetles (Coleoptera, Carabidae) of North America: Part II. Biology and behavior of Brachinus pallidus Erwin in California. Coleopterists Bulletin 21(2): 41-55.

Erwin TL (1969a) A new bombardier beetle in Canada (Coleoptera: Carabidae). Opuscula entomologica 34(3): 283-286.

Erwin TL (1969b) Preliminary diagnoses of five new North American Brachinus (Coleoptera: Carabidae). Opuscula entomologica 34(3): 287-288.

Erwin TL (1970a) A reclassification of bombardier beetles and a taxonomic revision of the North and Middle American species (Carabidae: Brachinida). Quaestiones entomologicae 6: 4-215.

Erwin TL (1970b) The Nearctic species of the Genus Leistus Frölich (Coleoptera: Carabidae). Pan-Pacific Entomologist 46: 111-119.

Erwin TL (1972) Observations on the life history of bombardier beetles: Mechanism of egg-hatching (Coleoptera: Carabidae). Pan-Pacific Entomologist 48(1): 1-64.

Erwin TL (1978) Systematic, natural history, and zoogeographic notes on the Genus Agra Fabricus, with a description of a new species from Panamá (Coleoptera: Carabidae: Lebiini). The Coleopterists Bulletin 32(4): 261-268.

Erwin TL (1979) Thoughts on the evolutionary history of ground beetles: Hypotheses generated from comparative faunal analyses of lowland forest sites in temperate and tropical regions. In: Erwin TL, Ball GE, Whitehead DR, Halpern AL (Eds) Carabid Beetles: Their evolution, natural history, and classification. Proceedings of the First International Symposium of Carabidology. Dr. W. Junk b.v. Publishers, The Hague, 539-592. https://doi. org/10.1007/978-94-009-9628-1_30

Erwin TL (1981) Taxon pulses, vicariance, and dispersal: An evolutionary synthesis illustrated by carabid beetles. In: Nelson G, Rosen D (Eds) Vicariance Biogeography: A Critique. Columbia University Press, New York, 159-183.

Erwin TL (1982a) Agra, arboreal beetles of Neotropical forests: erythropus group systematics (Carabidae). Systematic Entomology 7: 39-71. https://doi.org/10.1111/j.1365-3113.1982.tb00125.x

Erwin TL (1982b) Agra, arboreal beetles of Neotropical forests: platyscelis group systematics (Carabidae). Systematic Entomology 7: 185-210. https://doi.org/10.1111/j.1365-3113.1982. tb00131.x

Erwin TL (1983) Agra, arboreal beetles of Neotropical forests: famula and formicaria groups systematics (Carabidae). Systematic Entomology 8: 263-292. https://doi. org/10.1111/j.1365-3113.1983.tb00482.x

Erwin TL (1983) Baron Maximilien de Chaudoir: Chaudoir's studies of the taxa Agrina and Brachinitae (Coleoptera: Carabidae). The Coleopterists Bulletin 36(3): 501-511. 
Erwin TL (1984) Agra, arboreal beetles of Neotropical forests: palmata group systematics (Carabidae). Systematic Entomology 9: 9-48. https://doi.org/10.1111/j.1365-3113.1984. tb00499.x

Erwin TL (1985) The taxon pulse: A general pattern of lineage radiation and extinction among carabid beetles. In: Ball GE (Ed.) Taxonomy, phylogeny, and zoogeography of beetles and ants: A volume dedicated to the memory of Philip Jackson Darlington Jr. 1904-1983. Dr. W. Junk b.v. Publishers, The Hague, 437-472.

Erwin TL (1988) The tropical forest canopy: the heart of biotic diversity. In: Wilson EO (Ed.) Biodiversity. National Academy Press, Washington, 123-129.

Erwin TL (2002) The Beetle Family Carabidae of Costa Rica: Twenty-nine new species of Costa Rican Agra Fabricius 1801 (Coleoptera: Carabidae, Lebiini, Agrina). Zootaxa 119: 1-68. https://doi.org/10.11646/zootaxa.119.1.1

Erwin TL (2007) A treatise on the Western Hemisphere Carabidae (Coleoptera). Their classification, distribution s and ways of life (Vol. 1). Trachypachidae, Carabidae-Nebriiformes. Pensoft, Sofia, 323 pp.

Erwin TL (2011) A treatise on the Western Hemisphere Caraboidea (Coleoptera): Their classification, distributions, and way of life, Volume III (Carabidae - Loxomeriformes, Melaeniformes). Pensoft, Sofia, Moscow, 412 pp.

Erwin TL (2013) Beetles that live with ants (Carabidae, Pseudomorphini): A remarkable new genus and species from Guyane (French Guiana), Guyanemorpha spectabilis gen. n., sp. n. ZooKeys 358: 11-23. https://doi.org/10.3897/zookeys.358.6298

Erwin TL, Aldebron C (2018) Neotropical Thoasia Liebke, 1939 and Straneotia Mateu, 1961 of the Cryptobatida group, subtribe Agrina: Taxonomic revisions with notes on their ways of life (Insecta, Coleoptera, Carabidae, Lebiini). ZooKeys 742: 57-90. https://doi. org/10.3897/zookeys.742.22900

Erwin TL, Amundson L (2013) Beetles that live with ants (Carabidae, Pseudomorphini, Pseudomorpha Kirby 1825): A revision of the santarita species group. ZooKeys 362: 29-54. https://doi.org/10.3897/zookeys.362.6300

Erwin TL, Aschero V (2004) Cicindis horni Bruch (Coleoptera: Carabidae, Cicindini): The Fairy Shrimp Hunting Beetle, its way of life on the Salinas Grandes of Argentina. Zootaxa 553: 1-16. https://doi.org/10.11646/zootaxa.553.1.1

Erwin TL, Erwin LJM (1976) Relationships of predaceous beetles to tropical forest wood decay. Part II. The natural history of Neotropical Eurycoleus macularis Chevrolat (Carabidae: Lebiini) and its implications in the evolution of ectoparasitoidism. Biotropica 8: 215-224. https://doi.org/10.2307/2989713

Erwin TL, Halpern AL (1978) Max Bänninger: His collection and publications (Coleoptera: Carabidae). The Coleopterists Bulletin 32(4): 357-366.

Erwin TL, Kavanaugh DH (2000) A new species of the Tachyta subgenus Paratachyta Erwin (Coleoptera: Carabidae: Bembidiini: Tachyina) from Southeastern China with a new key and analysis of phylogenetic relationships among species of the subgenus. In: Zamotajlov A, Sciaky R (Eds) Advances in carabidology (Papers dedicated to the memory of Prof. Oleg L. Kryzhanovskij). MUISO publications, Krasnodar, 183-194. 
Erwin TL, Pearson DL (2008) A treatise of the western hemisphere Caraboidea (Coleoptera) their classification, distributions, and ways of life - Volume II (Carabidae - Nebriiformes 2 - Cicindelitae). Pensoft, Sofia, Moscow.

Erwin TL, Penev L, Stoev P, Georgiev T (2012) Accelerating innovative publishing in taxonomy and systematics: 250 issues of ZooKeys. ZooKeys 251: 1-10. https://doi.org/10.3897/ zookeys.251.4516

Erwin TL, Pimienta MC, Murillo OE, Aschero V (2005) Mapping patterns of $\beta$-diversity for beetles across the western Amazon Basin: A preliminary case for improving conservation strategies. Proceedings of the California Academy of Sciences, ser. 4, 56(Suppl. I) No. 7: 72-85.

Erwin TL, Stoev P, Georgiev T, Penev L (2015) ZooKeys 500: traditions and innovations handin-hand servicing our taxonomic community! ZooKeys 500: 1-8. https://doi.org/10.3897/ zookeys.500.9844

Erwin TL, Stork NE (1985) The Hiletini, an ancient and enigmatic tribe of Carabidae with a pantropical distribution (Coleoptera). Systematic Entomology 10: 405-451. https://doi. org/10.1111/j.1365-3113.1985.tb00149.x

Erwin TL, Zamorano LS (2014) A synopsis of the tribe Lachnophorini, with a new genus of Neotropical distribution and a revision of the Neotropical genus Asklepia Liebke, 1938 (Insecta, Coleoptera, Carabidae). ZooKeys 430: 1-108. https://doi.org/10.3897/zookeys.430.8094

Fauset S, Johnson MO, Gloor M, Baker TR, Monteagudo A, Brienen RJW, Feldpausch TR, Lopez-Gonzalez G, Malhi Y, ter Steege H, Pitman NCA, Baraloto C, Engel J, Petronelli P, Andrade A, Camargo J, Laurance SGW, Laurance WF, Chave J, Allie E, Vargas PN, Terborgh JW, Ruokolainen K, Silveira M, Aymard GA, Arroyo L, Bonal D, Ramirez-Angulo H, Araujo-Murakami A, Neill D, Herault B, Dourdain A, Torres-Lezama A, Marimon BS, Salomao RP, Comiskey JA, Rejou-Mechain M, Toledo M, Licona JC, Alarcon A, Prieto A, Rudas A, van der Meer PJ, Killeen TJ, Marimon BH, Poorter L, Boot RGA, Stergios B, Torre EV, Costa FRC, Levis C, Schietti J, Souza P, Groot N, Arets E, Moscoso VC, Castro W, Coronado ENH, Pena-Claros M, Stahl C, Barroso J, Talbot J, Vieira ICG, van der Heijden G, Thomas R, Vos VA, Almeida EC, Davila EA, Aragao L, Erwin TL, Morandi PS, de Oliveira EA, Valadao MBX, Zagt RJ, van der Hout P, Loayza PA, Pipoly JJ, Wang O, Alexiades M, Ceron CE, Huamantupa-Chuquimaco I, Di Fiore A, Peacock J, Camacho NCP, Umetsu RK, de Camargo PB, Burnham RJ, Herrera R, Quesada CA, Stropp J, Vieira SA, Steininger M, Rodriiguez CR, Restrepo Z, Muelbert AE, Lewis SL, Pickavance GC, Phillips OL (2015) Hyperdominance in Amazonian forest carbon cycling. Nature Communications 6: e6857. https://doi.org/10.1038/ncomms7857

Frank H, Erwin TL, Hemenway RC (2009) Economically beneficial ground beetles. The specialized predators Pheropsophus aequinoctialis (L.) and Stenaptinus jessoensis (Morawitz): Their laboratory behavior and descriptions of immature stages (Coleoptera: Carabidae: Brachininae). ZooKeys 14: 1-36. https://doi.org/10.3897/zookeys.14.188

Frankham R, Ballou JD, Briscoe DA (2009) Introduction to conservation genetics. Cambridge University Press, Cambridge, 617 pp. https://doi.org/10.1017/CBO9780511809002

Gerisch M, Agostinelli V, Henle K, Dziock F (2012) More species, but all do the same: contrasting effects of flood disturbance on ground beetle functional and species diversity. Oikos 121: 508-515. https://doi.org/10.1111/j.1600-0706.2011.19749.x 
Grammer JB (2021) Inspiration by estimation - how Terry Erwin affected my entomophilic attitude and most likely that of many other amateur entomologists. In: Spence J, Casale A, Assmann T, Liebherr JK, Penev L (Eds) Systematic Zoology and Biodiversity Science: A tribute to Terry Erwin (1940-2020). ZooKeys 1044: 993-999. https://doi.org/10.3897/ zookeys.1044.68650

Hennig W (1969) Die Stammesgeschichte der Insekten. Waldemar Kramer, Frankfurt am Main, 436 pp.

Homburg K, Homburg N, Schäfer F, Assmann T (2014) Carabids.org - A dynamic online database of ground beetle species traits (Coleoptera, Carabidae). Insect Conservation and Diversity 7: 195-205. https://doi.org/10.1111/icad.12045

Hunting W, Yang MM (2019) A taxonomic review of the pericaline ground-beetles in Taiwan, with descriptions of new species (Coleoptera: Carabidae, Lebiini). ZooKeys 816: 1-164. https://doi.org/10.3897/zookeys.816.29738

Kavanaugh DH (2020) Memories of a Beloved Friend. In Memoriam of Terry Lee Erwin (1 December 1940-11 May 2020). ZooKeys 936: 149-152.

Kremen C, Colwell RK, Erwin TL, Murphy DD, Noss RF, Sanjayan MA (1993) Terrestrial arthropod assemblages: Their use in conservation planning. Conservation Biology 7(4): 796-808. https://doi.org/10.3897/zookeys.936.54751

Kress WJ, Heyer WR, Acevedo-Rodriguez P, Coddington JA, Cole D, Erwin TL, Meggers BJ, Pogue MG, Thorington Jr RW, Vari RP, Weitzman MJ, Weitzman SH (1998) Amazonian biodiversity: Assessing conservation priorities with taxonomic data. Biodiversity and Conservation 7: 1577-1587. https://doi.org/10.1046/j.1523-1739.1993.740796.x

Lindroth CH, Bangsholt F, Baranowski R, Erwin TL, Jorum P, Landin B-O, Refseth D, Silfverberg H (1985) The Carabidae (Coleoptera) of Fennoscandia and Denmark. Fauna Entomologica Scandinavica 15: 1-225. https://doi.org/10.1023/A:1008889803319

Lindroth CH, Bangsholt F, Baranowski R, Erwin TL, Jorum P, Landin B-O, Refseth D, Silfverberg H (1986) The Carabidae (Coleoptera) of Fennoscandia and Denmark. Fauna Entomologica Scandinavica 15: 226-497.

Longino JT, Coddington J, Colwell RK (2002) The ant fauna of a tropical rain forest: Estimating species richness three different ways. Ecology 83: 689-702. https://doi.org/10.1890/00129658(2002)083[0689:TAFOAT]2.0.CO;2

Moritz C, Patton JL, Schneider CJ, Smith TB (2000) Diversification of rainforest faunas: An integrated molecular approach. Annual Review of Ecology and Systematics 31: 533-563. https://doi.org/10.1146/annurev.ecolsys.31.1.533

Nolte D, Schuldt A, Gossner MM, Ulrich W, Assmann T (2017) Functional traits drive ground beetle community structures in Central European forests: Implications for conservation. Biological Conservation 213, Part A: 5-12. https://doi.org/10.1016/j.biocon.2017.06.038 Novotny V, Basset Y (2005) Review - Host specificity of insect herbivores in tropical forests. Proceedings of the Royal Society B-Biological Sciences 272: 1083-1090. https://doi. org/10.1098/rspb.2004.3023

Ober KA (2003) Arboreality and morphological evolution in ground beetles (Carabidae: Harpalinae): Testing the taxon pulse model. Evolution 57: 1343-1358. https://doi. org/10.1111/j.0014-3820.2003.tb00342.x 
Penev L, Casale A, Banalieva Y (2021) Additions to the lists of publications of Terry Erwin, taxa described by him and named after him after 2015. In: Spence J, Casale A, Assmann T, Liebherr JK, Penev L (Eds) Systematic Zoology and Biodiversity Science: A tribute to Terry Erwin (1940-2020). ZooKeys 1044: 1037-1042. https://doi.org/10.3897/zookeys.1044.68650

Penev L, Cerretti P, Tschorsnig H-P, Lopresti M, Giovanni F, Georgiev T, Stoev P, Erwin T (2012) Publishing online identification keys in the form of scholarly papers. ZooKeys 205: 1-3. https://doi.org/10.3897/zookeys.205.3581

Penev L, Erwin T, Thompson FC, Sues H, Engel M, Agosti D, Pyle R, Ivie M, Assmann T, Henry T, Miller J, Casale A, Lourenço W, Golovatch S, Fagerholm H, Taiti S, AlonsoZarazaga M (2008) ZooKeys, unlocking Earth's incredible biodiversity and building a sustainable bridge into the public domain: From "print-based" to "web-based" taxonomy, systematics, and natural history. ZooKeys Editorial Opening Paper. ZooKeys 1: 1-7. https:// doi.org/10.3897/zookeys.1.11

Phillips OL, Aragao L, Lewis SL, Fisher JB, Lloyd J, Lopez-Gonzalez G, Malhi Y, Monteagudo A, Peacock J, Quesada CA, van der Heijden G, Almeida S, Amaral I, Arroyo L, Aymard G, Baker TR, Banki O, Blanc L, Bonal D, Brando P, Chave J, de Oliveira ACA, Cardozo ND, Czimczik CI, Feldpausch TR, Freitas MA, Gloor E, Higuchi N, Jimenez E, Lloyd G, Meir P, Mendoza C, Morel A, Neill DA, Nepstad D, Patino S, Penuela MC, Prieto A, Ramirez F, Schwarz M, Silva J, Silveira M, Thomas AS, ter Steege H, Stropp J, Vasquez R, Zelazowski P, Davila EA, Andelman S, Andrade A, Chao KJ, Erwin T, Di Fiore A, Honorio E, Keeling H, Killeen TJ, Laurance WF, Cruz AP, Pitman NCA, Vargas PN, Ramirez-Angulo H, Rudas A, Salamao R, Silva N, Terborgh J, Torres-Lezama A (2009) Drought sensitivity of the Amazon Rainforest. Science 323: 1344-1347. https://doi.org/10.1126/science.1164033

Saska P, Honek A (2004) Development of the beetle parasitoids, Brachinus explodens and B. crepitans (Coleoptera: Carabidae). Journal of Zoology 262: 29-36. https://doi.org/10.1017/ S0952836903004412

Schuldt A, Wubet T, Buscot F, Staab M, Assmann T, Böhnke-Kammerlander M, Both S, Erfmeier A, Klein AM, Ma KP, Pietsch KA, Schultze S, Wirth C, Zhang JY, Zumstein P, Bruelheide H (2015a) Multitrophic diversity in a biodiverse forest is highly nonlinear across spatial scales. Nature Communications 6: e10169. https://doi.org/10.1038/ ncomms10169

Spence J, Kavanaugh D, Maddison DR, Boyd O, Brandmayr P, Garner B, Maveety S, Mosquera D, Moore W, Riley K, Shorthouse J, Sims L, Steiner W, Swing K, Turin H, Zamorano LS, Penev L (2021) Memories of Terry Erwin. In: Spence J, Casale A, Assmann T, Liebherr JK, Penev L (Eds) Systematic Zoology and Biodiversity Science: A tribute to Terry Erwin (1940-2020). ZooKeys 1044: 1001-1036. https://doi.org/10.3897/zookeys.1044.68648

Staab M, Schuldt A (2020) The influence of tree diversity on natural enemies - a review of the "Enemies" hypothesis in forests. Current Forestry Reports 6: 243-259. https://doi. org/10.1007/s40725-020-00123-6

Stoev P, Penev L, Akkari N, Cheung DK-B, Enghoff H, Brunke A, de Souza CM, Pape T, Mietchen D, Erwin T (2013) Revolving images and multi-image keys open new horizons in descriptive taxonomy: ZooKeys working examples. ZooKeys 328: 1-3. https://doi. org/10.3897/zookeys.328.6171 
Stork NE (1991) The composition of the arthropod fauna of Bornean lowland rain-forest trees. Journal of Tropical Ecology 7: 161-180. https://doi.org/10.1017/S0266467400005319

Stork NE (2018) How many species of insects and other terrestrial arthropods are there on Earth? Annual Review of Entomology 63: 31-45. https://doi.org/10.1146/annurev-ento-020117-043348

Sullivan MJP, Talbot J, Lewis SL, Phillips OL, Qie L, Begne SK, Chave J, Cuni-Sanchez A, Hubau W, Lopez-Gonzalez G, Miles L, Monteagudo-Mendoza A, Sonke B, Sunderland T, Ter Steege H, White LJT, Affum-Baffoe K, Aiba S, de Almeida EC, de Oliveira EA, Alvarez-Loayza P, Davila EA, Andrade A, Aragao L, Ashton P, Aymard GA, Baker TR, Balinga M, Banin LF, Baraloto C, Bastin JF, Berry N, Bogaert J, Bonal D, Bongers F, Brienen R, Camargo JLC, Ceron C, Moscoso VC, Chezeaux E, Clark CJ, Pacheco AC, Comiskey JA, Valverde FC, Coronado ENH, Dargie G, Davies SJ, De Canniere C, Djuikouo MN, Doucet JL, Erwin TL, Espejo JS, Ewango CEN, Fauset S, Feldpausch TR, Herrera R, Gilpin M, Gloor E, Hall JS, Harris DJ, Hart TB, Kartawinata K, Kho LK, Kitayama K, Laurance SGW, Laurance WF, Leal ME, Lovejoy T, Lovett JC, Lukasu FM, Makana JR, Malhi Y, Maracahipes L, Marimon BS, Marimon B, Marshall AR, Morandi PS, Mukendi JT, Mukinzi J, Nilus R, Vargas PN, Camacho NCP, Pardo G, Pena-Claros M, Petronelli P, Pickavance GC, Poulsen AD, Poulsen JR, Primack RB, Priyadi H, Quesada CA, Reitsma J, Rejou-Mechain M, Restrepo Z, Rutishauser E, Abu Salim K, Salomao RP, Samsoedin I, Sheil D, Sierra R, Silveira M, Slik JWF, Steel L, Taedoumg H, Tan S, Terborgh JW, Thomas SC, Toledo M, Umunay PM, Gamarra LV, Vieira ICG, Vos VA, Wang O, Willcock S, Zemagho L (2017) Diversity and carbon storage across the tropical forest biome. Scientific Reports 7. https://doi.org/10.1038/srep39102

Tewksbury JJ, Anderson JGT, Bakker JD, Billo TJ, Dunwiddie PW, Groom MJ, Hampton SE, Herman SG, Levey DJ, Machnicki NJ, Del Rio CM, Power ME, Rowell K, Salomon AK, Stacey L, Trombulak SC, Wheeler TA (2014) Natural history's place in science and society. Bioscience 64: 300-310. https://doi.org/10.1093/biosci/biu032

ZooKeys Editorial Office (2015) Celebrating with the 'beetle' man: Terry Erwin's 75th birthday. ZooKeys 541: 1-40. https://doi.org/10.3897/zookeys.541.7316

Zumstein P, Bruelheide H, Fichtner A, Schuldt A, Staab M, Härdtle W, Zhou H, Assmann T (2021) What shapes ground beetle assemblages in a tree species-rich subtropical forest? In: Spence J, Casale A, Assmann T, Liebherr JK, Penev L (Eds) Systematic Zoology and Biodiversity Science: A tribute to Terry Erwin (1940-2020). ZooKeys 1044: 907-1036. https://doi.org/10.3897/zookeys.1044.63803 